\title{
Quality of life after laparoscopic sleeve gastrectomy - review of literature
}

\author{
Mateusz Wityk ${ }^{1}{ }^{\circ}$, Wojciech Makarewicz² ${ }^{\circ}$, \\ Cezary Kaczmarkiewicz' ${ }^{10}$, Maciej Bobowicz²
}

${ }^{1}$ Department of General and Oncological Surgery, Voivodeship Specialist Hospital of Janusz Korczak in Słupsk, Poland

${ }^{2}$ Department of Oncological Surgery, Medical University of Gdańsk, Poland

\begin{abstract}
Background: The last decade brought changes the most frequently performed types of bariatric procedures. Despite the well-documented positive impact of bariatric surgery on depression, somatic comorbidities, lifespan prolongation and cancer risk, there is still insufficient data on patients' quality of life (QoL) after this operation. Methods: PubMed and Scopus databases as well as Mendeley search engine were used to find publications from last ten years focusing on QoL after LSG. 702 abstracts were reviewed. 13 articles with 1630 patients in total were analyzed. Results: Six different QoL assessment tools were described in the reviewed literature: SF-36, BAROS, Moorehead-Ardelt II questionnaire, IWQOL-Lite, GIQLI and SF8. In majority of studies the QoL was improved. Preand postoperative assessment with SF-36 showed significant improvement. The mean BAROS score was 5.1-7.1 with $77-96 \%$ of patients achieving "good" to "excellent" outcomes. In some studies, QoL was better in females and in one study QoL was below the general population norms. Some studies demonstrated lack of improvement in QoL after LSG or no correlation between excess weight loss and health related QOL. Conclusions: High quality research about QoL after LSG is limited, though quality of life seems to be better after that procedure.
\end{abstract}

Keywords: bariatric surgery $\cdot$ metabolic surgery $\cdot$ BAROS $\cdot$ SF-36 $\cdot$ QoL

\section{Citation}

Wityk M, Makarewicz W, Kaczmarkiewicz C, Bobowicz M. Quality of life after laparoscopic sleeve gastrectomy - review of literature. Eur J TransI Clin Med. 2019;2(2):52-60.

DOI: $10.31373 /$ ejtcm/112077

Corresponding author:

Mateusz Wityk, Department of General and Oncological Surgery, Voivodeship Specialist Hospital of Janusz Korczak in Słupsk, Poland

e-mail: mateuszwityk@gmail.com

No external funds.

Available online: www.ejtcm.gumed.edu.pl

Copyright ${ }^{\circledR}$ Medical University of Gdańsk

This is Open Access article distributed under the terms of the Creative Commons Attribution-ShareAlike 4.0 International. 


\section{Introduction}

Obesity increases the risk of metabolic, cardiovascular and musculoskeletal diseases, depression and several types of cancer. In addition, obesity might lead to reduced quality of life, lower productivity and social disadvantages [1]. Obesity also decreases life expectancy [2]. The worldwide prevalence of overweight and obesity has doubled since 1980 to an extent that nearly a third of the world's population is currently classified as overweight or obese [3].

The superiority of surgery over conservative treatment for obesity and related diseases has been proven for many years [4]. Last decade brought changes in the trends of most frequently performed types of operations. A 2018 Worldwide Survey published by the International Federation for the Surgery of Obesity and Metabolic Disorders (IFSO) showed that the most frequently performed primary surgical bariatric/ metabolic procedure in 2016 was laparoscopic sleeve gastrectomy (LSG) (53.6\%), followed by Roux-en-Y gastric bypass (30.1\%) and one-anastomosis gastric bypass $(4.8 \%)[5]$.

The first sleeve gastrectomy was performed in 1988 as part of the biliopancreatic diversion with duodenal switch and since 2004 was accepted as a stand-alone bariatric procedure [6]. In the following years it became the most common type of surgical treatment of obesity in Poland (62\%) and worldwide [5].

There are several measurable outcomes of bariatric surgery such as weight loss, resolution or improvement of comorbidities and an increase in life expectancy. One of the most important patient-reported outcomes, which is defining failure or success of bariatric surgery is Health-Related Quality of Life (HRQoL), however only few published studies focused on this end point [7-8]. There is some original research and literature reviews about QoL after bariatric surgery, comparing various methods of surgical technique [9]. Nevertheless, to our best knowledge, there are no reviews focusing directly on QoL after LSG and the relevant articles started to appear well after 2004 (2). In perspective of rising popularity of the LSG as the surgical treatment of choice for obesity, our aim was to assess the impact of this procedure on patients' quality of life (QoL).

\section{Material \& Methods}

In 2010 LSG became the most frequently performed bariatric procedure in Poland, and thus our decision to include publications from the last 10 years [10]. We searched relevant publications that investigated adult participants (both sexes) who underwent LSG for obesity and underwent assessment of QoL at least once after 6-months of follow-up (or longer) with one of the well-established and validated tools for the QoL assessment (The 36-Item Short Form Health Survey (SF-36), Bariatric Analysis and Reporting Outcome System (BAROS) and it's updated version, The Moorehead-Ardelt Quality of Life Questionnaire (MA-II), The Impact of Weight on Quality of Life - Lite Questionnaire (IWQOL-Lite), The Gastrointestinal Quality of Life Index (GIQLI) and The 8-Item Short Form Health Survey (SF-8) [11-18]. We took into consideration all QoL outcomes depending on the design of the QoL form and the primary outcome was the change in the total score of the QoL assessment after LSG.

In this review we used PubMed and Scopus databases as well as Mendeley search engine for articles from last ten years focusing on quality of life after LSG. Search strategy was based on terms "sleeve gastrectomy" and "laparoscopy"/or "LSG" and "quality of life"/ or "QoL" and was performed independently by two researchers (MW and $\mathrm{MB}$ ). We excluded case reports, reviews, letters, duplicate studies, pediatric patients ( $<18$ years of age), studies with patient samples smaller than 50 patients $(\mathrm{n}<50)$ and studies involving bariatric procedures other than LSG [e.g. laparoscopic Roux-en-Y gastric bypass (LRYGB), single-anastomosis gastric bypass (SAGB) or mini-gastric bypass (MGB), adjustable gastric banding (AGB)].

\section{Results}

\section{Literature search}

Initial search returned 702 abstracts (see Figure 1). Of those, 25 abstracts met the inclusion criteria. Full-texts of articles were obtained and reviewed. 12 articles were excluded for reasons such as analyzing the same groups of patients, using not validated QoL questionnaires or small patient samples $(n<50)$. We included 13 articles in the final analysis, with a total of 1630 patients and extracted the data (see Figure 1).

\section{Patient Characteristics}

In A total of 1630 adults underwent LSG as a treatment for morbid obesity. 1151 were female and 416 were male. BMI and age of patients are contained in Table 1. 
Records identified through database search

$$
(n=702)
$$

\section{$\downarrow$}

\section{Records screened}

$(n=702)$

$\downarrow$

Full-text articles assessed for eligibility

$$
(n=25)
$$

$\downarrow$

Studies included in the systematic review

$$
(n=13)
$$

Records excluded

$$
(n=677)
$$

Full-text articles excluded $(n=12)$ :

- identical patient samples $(n=2)$

- QoL questionnaires not validated or

not related to surgical procedure $(n=3)$

\begin{tabular}{|c|c|c|c|c|c|c|c|c|}
\hline Author & $\begin{array}{c}\text { Year } \\
\text { published }\end{array}$ & $\begin{array}{l}\text { Patient } \\
\text { number } \\
\text { (F=Female } \\
\text { M=Male) }\end{array}$ & $\begin{array}{c}\text { Mean } \\
\text { patient age } \\
\text { (years) }\end{array}$ & $\begin{array}{c}\text { Mean } \\
\text { preoperative } \\
\text { BMI }\left[\mathbf{k g} / \mathbf{m}^{2}\right]\end{array}$ & $\begin{array}{l}\text { Question- } \\
\text { naire type }\end{array}$ & $\begin{array}{l}\text { Follow-up } \\
\text { (months) }\end{array}$ & $\begin{array}{c}\text { Preope- } \\
\text { rative } \\
\text { (PRE) or } \\
\text { Postope- } \\
\text { rative } \\
\text { (POS) } \\
\text { QoL } \\
\text { analysis }\end{array}$ & $\begin{array}{c}\text { QoL } \\
\text { improvement } \\
\text { ( } \% \text { of } \\
\text { patients) }\end{array}$ \\
\hline $\begin{array}{c}\text { Akan S } \\
\text { et al. [21] }\end{array}$ & 2018 & 53 (F53) & $34.85 \pm 9.38$ & $47.43 \pm 6.37$ & SF-36 & N/A & $\begin{array}{c}\text { PRE } \\
+ \text { POS }\end{array}$ & $\begin{array}{c}\text { Significantly } \\
\text { improved } \\
(p<0.001)\end{array}$ \\
\hline $\begin{array}{c}\text { Bobowicz M } \\
\text { et al. [30] }\end{array}$ & 2011 & $\begin{array}{c}84 \text { (F63, } \\
\text { M21) }\end{array}$ & $39 \pm 12.09$ & $44.62 \pm 8.17$ & BAROS & $\begin{array}{c}\text { Mean } \\
22 \pm 6.75\end{array}$ & POS & $\begin{array}{l}\text { Improved ( } 77.5 \% \\
\text { of "excellent," } \\
\text { "very good" and } \\
\text { "good" scores) }\end{array}$ \\
\hline $\begin{array}{l}\text { Charalam- } \\
\text { pakis V } \\
\text { et al.[22] }\end{array}$ & 2018 & $\begin{array}{c}95 \text { (F50, } \\
\text { M45) }\end{array}$ & $37.4 \pm 9.2$ & $48.3 \pm 7.1$ & $\begin{array}{l}\text { Moorehead- } \\
\text {-Ardelt II }\end{array}$ & 60 & $\begin{array}{l}\text { PRE } \\
+ \\
\text { POS }\end{array}$ & $\begin{array}{l}\text { Significantly } \\
\text { improved } \\
(p<0.001)\end{array}$ \\
\hline $\begin{array}{l}\text { D'Hondt M } \\
\text { et al. [27] }\end{array}$ & 2011 & $\begin{array}{l}83 \\
(F 61, \\
M 22)\end{array}$ & 40.4 & 39.3 & $\begin{array}{l}\text { BAROS, } \\
\text { SF-36 }\end{array}$ & $\begin{array}{c}\text { Median } 49 \\
(17-80)\end{array}$ & POS & $\begin{array}{l}90.4 \% \text { of "good" and } \\
\text { "excellent" BAROS sco- } \\
\text { res. The SF-36 scores } \\
\text { for 'physical functioning' } \\
\text { ( } p=0.030 \text { ) and 'gene- } \\
\text { ral health perception' } \\
(p=0.017 \text { ) were better } \\
\text { for the patients with a } \\
\% \text { EWL greater than } 50 \%\end{array}$ \\
\hline
\end{tabular}

- small $(n<50)$ patient samples $(n=7)$

Figure 1. Literature search

Table 1. Data summary of included publications 


\begin{tabular}{|c|c|c|c|c|c|c|c|c|}
\hline $\begin{array}{l}\text { Fezzi M } \\
\text { et al. } \\
\text { [23] }\end{array}$ & 2011 & $\begin{array}{l}77 \\
(F 54, \\
\text { M23) }\end{array}$ & 42.4 & 47 & $\begin{array}{c}\text { SF-36, } \\
\text { IWQOL-Lite }\end{array}$ & 12 & $\begin{array}{c}\text { PRE } \\
+ \\
\text { POS }\end{array}$ & $\begin{array}{c}\text { Significantly } \\
\text { improved SF-36 } \\
(p<0.001) \text { and } \\
\text { IWQOL-Lite } \\
(p<0.001)\end{array}$ \\
\hline $\begin{array}{c}\text { Figura A } \\
\text { et al. } \\
\text { [19] }\end{array}$ & 2016 & $\begin{array}{c}59 \\
(\mathrm{~N} / \mathrm{A})^{* *} \\
63(\mathrm{~F} 45, \\
\mathrm{M} 18)\end{array}$ & $\begin{array}{c}45.6 \\
\pm \\
10.9\end{array}$ & $\begin{array}{l}51.5 \\
\pm \\
8.1\end{array}$ & SF-8 & $\begin{array}{l}\text { Mean } \\
19 \pm 6\end{array}$ & $\begin{array}{c}\text { PRE } \\
+ \\
\text { POS }\end{array}$ & $\begin{array}{l}\text { Significant impro- } \\
\text { vement in physical } \\
\text { health }(p<0.001) \text {. } \\
\text { Mental health did not } \\
\text { change significantly } \\
(p>0.05)\end{array}$ \\
\hline $\begin{array}{l}\text { Flølo TN } \\
\text { et al. } \\
\text { [28] }\end{array}$ & 2017 & $\begin{array}{l}136 \\
(\mathrm{~F} 97 \\
\mathrm{M} 39)\end{array}$ & $40.3 \pm 10.5$ & $46.2 \pm 6.4$ & SF-36 & 60 & POS & $\begin{array}{c}\text { Significant } \\
\text { improvement } \\
(p<0.001)\end{array}$ \\
\hline $\begin{array}{l}\text { Gallart- } \\
\text {-Aragon T } \\
\text { et al. [24] }\end{array}$ & 2018 & $\begin{array}{l}72 \\
(\mathrm{~F} 47 \\
\mathrm{M} 25)\end{array}$ & $\begin{array}{l}45.36 \\
\pm \\
9.38\end{array}$ & N/A & GIQLI & 6 & $\begin{array}{l}\text { PRE } \\
+ \\
\text { POS }\end{array}$ & $\begin{array}{l}\text { Significant improve- } \\
\text { ment in total GIQLI } \\
\text { score }(p<0.001)\end{array}$ \\
\hline $\begin{array}{l}\text { Hosseini } \\
\text { SV et al. } \\
\text { [29] }\end{array}$ & 2018 & $\begin{array}{l}120 \\
(F 95, \\
\text { M25) }\end{array}$ & $\begin{array}{l}35.23 \\
\pm \\
10.05\end{array}$ & 48.87 & $\begin{array}{l}\text { Moorehead- } \\
\text {-Ardelt II, } \\
\text { SF-36 }\end{array}$ & $\begin{array}{l}\text { Median } \\
14.5 \\
(2-46)\end{array}$ & POS & $\begin{array}{c}\text { No significant } \\
\text { difference in MAII } \\
\text { score before and } \\
\text { after operation (good } \\
\text { to excellent in } 90 \% \text { ). } \\
\text { SF-36 scores were } \\
\text { statistically different } \\
\text { in all parameters } \\
(p<0.05 \text { ) except } \\
\text { for 'role limitations } \\
\text { attributed to } \\
\text { emotional problems' } \\
\text { and 'mental health' } \\
\text { with no significant } \\
\text { difference } \\
\text { ( } p=0.080,0.074, \\
\text { respectively) }\end{array}$ \\
\hline $\begin{array}{l}\text { Kirkil C } \\
\text { et al. } \\
\text { [20] }\end{array}$ & 2018 & $\begin{array}{l}562 \\
(F 399, \\
M 163)\end{array}$ & $\begin{array}{c}34.1 \\
\pm \\
8.1\end{array}$ & $\begin{array}{c}45.4 \\
\pm \\
5.4\end{array}$ & BAROS & $\begin{array}{c}\text { Mean } \\
7.4 \pm 5.3\end{array}$ & POS & $\begin{array}{l}\text { Good to excellent } \\
\text { BAROS score in } \\
80.1 \% \text { of patients. } \\
\text { The mean QoL scores } \\
\text { were significantly } \\
\text { increased after LSG } \\
\text { (range, } p<0.05 \\
\text { to }<0.001 \text { ) }\end{array}$ \\
\hline $\begin{array}{l}\text { Porta A } \\
\text { et al. *** } \\
\text { [25] }\end{array}$ & 2016 & $\begin{array}{l}130 \\
(\mathrm{~F} 104 \\
\mathrm{M} 26)\end{array}$ & $\begin{array}{l}\text { CL } 39 \\
\pm 2.3 \\
\text { SI } 36 \\
\pm 2.9\end{array}$ & $\begin{array}{l}\text { CL } 41.01 \\
\quad \pm 0.4 \\
\text { SI } 40.09 \\
\quad \pm 0.3\end{array}$ & SF-36 & 12 & $\begin{array}{l}\text { PRE } \\
+ \\
\text { POS }\end{array}$ & $\begin{array}{c}\text { Significant } \\
\text { improvement in all } \\
\text { items of SF-36 in CL } \\
\text { and SI groups } \\
\text { (both } \mathrm{p}<0.05 \text { ) }\end{array}$ \\
\hline
\end{tabular}




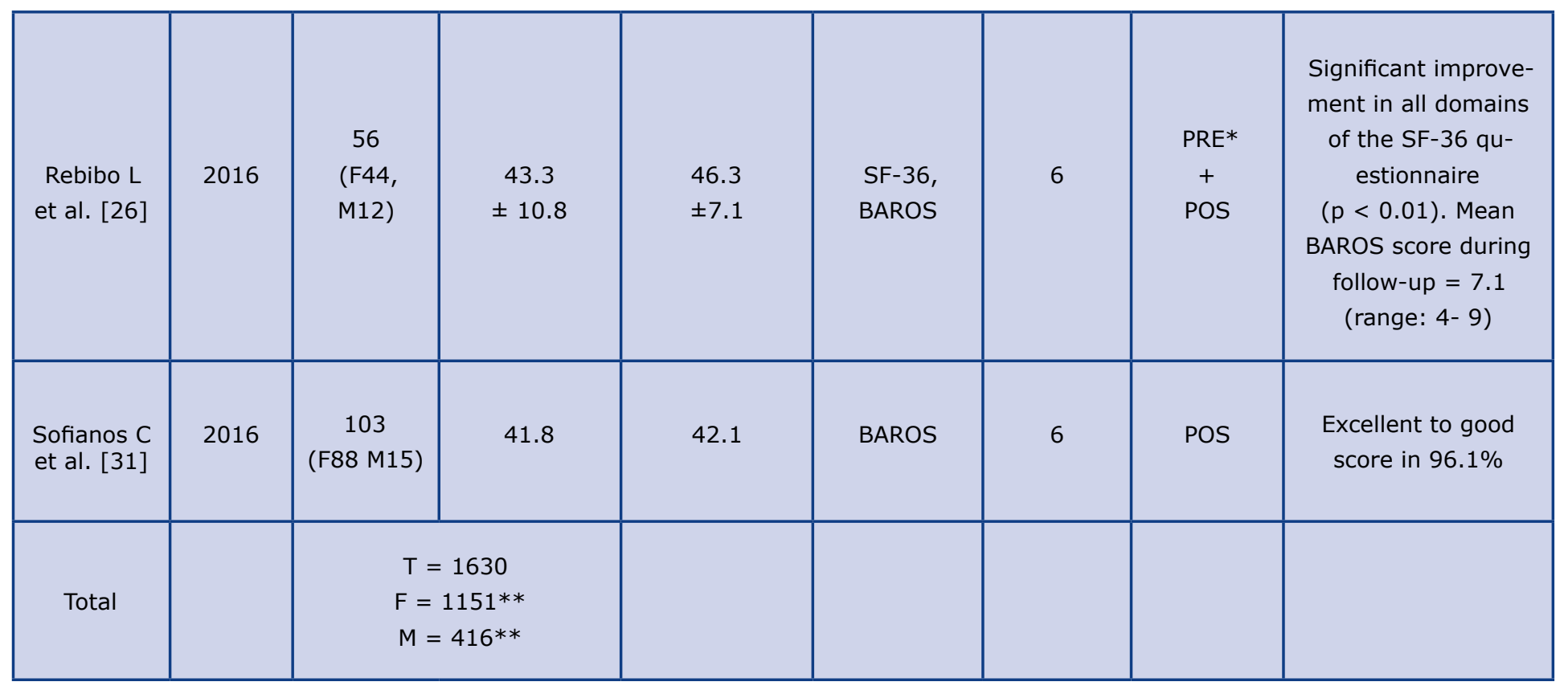

*Preoperative data available only for SF-36

**Gender results were corrected according to Figura et al. - N/A data of 4 excluded person gender

$* * *$ Two groups of patients: $\mathrm{CL}=$ Conventional LSG, $\mathrm{SI}=$ Single incision LSG

\section{Quality of life}

In The most frequently used questionnaires were SF-36 (in 7 studies), BAROS (5; twice authors used the updated version) and Moorehead-Ardelt II questionnaire (2). IWQOL-Lite, GIQLI and SF8 forms were used in one study each [11, 13-18].

Design varied significantly between studies with relatively short follow-up $<12$ months in 6 studies and $>12$ months in the remaining 7 studies. Majority of the articles $(\mathrm{N}=8)$ included data for small study groups (50 100 patients), 4 studies had 100-200 participants and only 1 analyzed > 500 patients (Tab.1) [20]. Only 7 studies incorporated preoperative analysis of QoL [19, 21-26].

\section{SF-36}

The SF-36 questionnaire was used in 7 publications four times set together with another questionnaire [21, 23, 25-29]. Studies by Akan et al., Fezzi et al., Porta et al. and Rebibo et al. demonstrated significant improvement in all domains of the SF-36 in 6 and 12 months after surgery compared to preoperative scores [21, 23, 25-26]. Moreover, Akan et al. showed prominent postoperative improvement in the physical and mental components of the SF-36 questionnaire comparing with preoperative scores [21].

In a postoperative analysis by D'Hondt et al., patients with a percent excess weight loss (\%EWL) > 50\% at median 49 months of observation had higher SF-36 scores for 'physical functioning' and 'general health' perception [27]. Hosseini et al. compared a group of candidates for surgery with patients after LSG. SF-36 scores were statistically different in all parameters except mental health and role limitation due to emotional problems [29].

Fezzi et al. showed significant improvement in all domains of SF-36, but there was no statistically significant correlation between weight loss and the QoL [23]. Porta et al. additionally investigated the influence of classical or single incision LSG on QoL, showing no difference in QoL outcomes between the groups [25].

Flølo et al. checked QoL 5 years after sleeve gastrectomy and compared it with a baseline cohort of obese patients eligible for LSG and a cohort representative of the Norwegian general population. The mental and physical summary scores were better at 5-year follow-up compared with baseline cohort but were below the normal results of the rest of the population. Authors showed no correlation between \%EWL and HRQOL score at 5-year follow-up [28].

\section{BAROS}

The BAROS questionnaire was used in 5 studies, twice it was paired with the SF-36 [20, 26, 27, 30-31]. In 2 studies the authors used the updated version of BAROS [14, 20, 27]. In both versions this questionnaire merges \%EWL, improvement of comorbidities, QoL in self-esteem, physical activity, social, labor and sexual 
aspects, allowing complex assessment of outcomes in bariatric surgery.

The BAROS questionnaire was completed by patients in Sofianos et al. study with good to excellent outcomes achieved in $96.1 \%$ of patients at the 6-month follow-up and the mean BAROS score was 5.1 (range 1.9-8.7, max. possible score $=9$ ) [31]. Rebibo et al. checked QoL after 6 months of follow-up using previous version of BAROS. Mean postoperative BAROS score was 7.1 (range 4-9) which means that the entire study group (56 patients) achieved an excellent outcome, although no precise information about the distribution of outcomes was included [26]. Slightly less optimistic results are published Kirkil et al. in their study on 562 respondents: "good" to "excellent" outcomes in $80 \%$ of patients (19.6\% "excellent," $25.6 \%$ "very good," $34.9 \%$ "good") at 7.4 \pm 5.3 months of follow up [20]. Bobowicz et al. showed that "excellent," "very good" and "good" scores were achieved in $77.5 \%$ of patients, at the mean 22 months of follow up. In their study, females achieved significantly better result than males [30]. D'Hondt et al. also presented "good" to "excellent" score in $90,4 \%$ of responders at significantly longer time of observation with median of 49 months [27]. On the other hand, "fair" results were observed in $3.9-15.3 \%$ of patients in all studies, and failures varied between 0-13\% [20, 30-31].

\section{Moorehead-Ardelt quality of life questionnaire (MAII)}

Moorehead-Ardelt quality of life questionnaire (MAII) was used in 2 studies [22, 29], once together with the SF-36 [29]. Charalampakis et al. showed significant improvement in QoL after LSG that was observed at all postoperative time points, despite the decline between the 2 nd and the 5 th year of follow-up. The MAll score increased from $-0.38 \pm 1.3$ preoperatively to $1.77 \pm$ 0.8 (6 months), $2.08 \pm 0.8$ (12 months), $2.12 \pm 0.7$ (24 months) and $1.67 \pm 1.1$ at 60 months postoperatively. In final, there were only four patients classified with "poor" outcome and no patients in "very poor" group in MAll score at 5 years after operation. This study also showed that QoL improvement is higher in females [22]. Hosseini et al. showed that after median 14.5 months of follow up the median MAll score was $6.48 \pm 0.45$. Thus, the "good" to "excellent" scores were observed in $90 \%$ of patients but there was no statistically significant difference in comparison to control group [29].

\section{Impact of Weight on Quality of Life - Lite (IWQOL)}

Impact of Weight on Quality of Life - Lite (IWQOL) questionnaire in connection with SF-36 form was used by Fezzi et al. in their study with 12-month follow-up of 77 patients [23]. The scores of five areas of IWQOL-Lite showed an improvement of the quality of life connected to the loss of weight for all the dimensions: physical function, self-esteem, sexual life, public distress, and work. Their key finding is a significant change for every dimension of QoL, but there was no statistically significant correlation between the QoL and weight loss in 1-year follow-up. Researchers commented that the self-esteem was the only aspect of QoL that improved and was directly related to the \%EWL [23].

\section{The Gastrointestinal Quality of Life Index (GIQLI)}

The Gastrointestinal Quality of Life Index (GIQLI) questionnaire was used by Gallart-Aragon et al. for evaluation of QoL before and 6 months after the operation. Authors showed significant improvements in all, except one aspect (emotional condition) of the GIQLI and total GIQLI score after half a year [24].

\section{Short Form Health Survey (SF-8)}

Short Form Health Survey (SF-8) was used by Figura et al. to assess and compare QoL in two groups of patients before and after LSG with outcomes of patients undergoing conservative treatment (i.e. dietary advice, physical exercise etc.). LSG patients' results, within-group comparisons, showed a significant increase in physical health, whereas mental health did not change significantly. For perceived physical health or mental health statistically significant post interventional group differences could not be identified. Important information is that four LSG patients failed to fill out the SF-8 questionnaire and were excluded from the analysis - there is no information about the sex of excluded patients [19].

\section{Discussion}

The LSG became a stand-alone procedure just in 2004. We aimed to find studies that have adequate follow-up time and did not include patients from the surgeons' "learning-curve" years. Therefore we focused on studies conducted in 2008-2018, when bariatric teams mastered the LSG technique.

QoL in bariatric surgery has been broadly investigated, nevertheless we couldn't find any review focusing directly on QoL changes following LSG [8-9, 32]. In the context of the epidemiological forecasts for obesity and the increasing implementation of LSG worldwide, it seems reasonable to intensify the research efforts on obesity treatment outcomes [5, 
33-34]. The positive influence of bariatric surgery on obesity-related comorbidities is well known and QoL is an undisputable part of bariatric outcomes [35-37]. Evaluation of quality of life appears to be a very important parameter both for patients and surgeons. The same conclusion was made in review by Rausa et al, which compared quality of life after LSG and LRYGB [9]. The authors stated that there was no difference in QoL regardless which of the two surgical approaches was used. It leads to conclusion that patient's and surgeon's preference may play an important role in choice of surgical procedure [9].

Based on our literature review, we can state that almost all studies showed improvement in HRQOL after LSG in 6-80 months follow-up in adult population (Tab.1). It is easy to observe, mainly in studies using BAROS score, 77-96\% of patients achieving "good" to "excellent" outcomes with improvement in the Moorehead-Ardelt QoL Questionnaire assessing such factors as self-esteem, physical activity, social engagement, ability to work, and sexual life. Sleeve gastrec tomy shows promising results not only in pathological obesity but also class I obesity resulting in early weight loss and significant QoL improvement [38]. Some studies show that female patients achieve better QoL than male patients after bariatric surgery $[22,30]$. LSG improves women's sexual function according to study by Akan et al., and reduces urinary dysfunction among males [21].

The benefit of LSG in terms of HRQOL improvement was also proven in older patients $>55$ years of age, which interestingly was even higher than in younger groups [39-40]. Both studies also showed safety of this procedure in older patients. Similar outcomes such as resolution of co-morbidities and improvement in QoL were observed independently by Boza et al. in adolescents [41].

On the contrary, some studies demonstrated no significant difference in some aspects of QoL after LSG $[19,23,25,29]$. What is even more interesting, Flølo et al. showed that despite the significantly better HRQOL after LSG compared to the baseline cohort, the study population did not reach population norms [28]. In our opinion, this is a serious limitation of all $\mathrm{HRQOL}$ research in obese patients. Most of the researchers concentrate on the improvement of QoL after surgery with no reference to healthy volunteers neither to the pre-operative situation. This might be a goal for further research in obesity management.

Obesity surgery has some additional limitations influencing HRQOL such as worse food tolerance after LSG in up to $5 \%$ of patients in comparison to non-obese patients who had no surgery [27]. The very good news is that most recent studies show satisfactory postoperative reflux control in the majority of patients and low rates of de novo GERD after laparoscopic sleeve gastrectomy [37]. Currently there are several modern methods for data collection, follow-up and communication between surgeons and patients such as text messages or social media which could be considered in the holistic approach towards patients with obesity and present-day surgery [20,42].

Major limitations of our study are: heterogeneity of all the reviewed studies, different designs and different QoL tools applied (six different HRQOL questionnaires) that bring in many sources of bias and make the results difficult to compare. Exclusion and inclusion of patients undergoing different bariatric procedures, lack of pre-operative assessment and non-uniform statistical reporting resulted in mainly descriptive and not quantitative analysis. Other limitations are small groups of patients included and different methodology used for quality of life data collection. Moreover, in some studies, there was limited or lacking information on patients' characteristics such as age, gender, BMI etc.

\section{Conclusions}

Despite all the limitations of the reviewed studies and different HRQOL tools used, almost all of the reviewed studies showed improvement in QoL following sleeve gastrectomy. It is difficult to assess which QoL tool is the most appropriate bariatric surgery patients. None of the tools assessed is perfect, but when used properly they can provide important information about postoperative course. Such information can then be used to adequately prepare for surgery and choose the best operative technique. Further research about this subject is needed, particularly controlled and long-term studies, with unified data collection and statistical analysis. In our opinion, quality of life after laparoscopic sleeve gastrectomy should be checked routinely during follow-up visits, same as BMI or \%EWL.

\section{Funding}

There was no external funding for conducting this study.

\section{Conflict of interest}

The authors declare no conflicts of interest regarding the publishing of this article. 


\section{References}

1. Blüher M. Obesity: global epidemiology and pathogenesis. Nat Rev Endocrinol [Internet]. 2019;15(5):288-98. Available from: http://www.nature.com/articles/s41574-019-0176-8

2. Preedy VR, Watson RR, editors. Years of Life Lost Due to Mortality BT - Handbook of Disease Burdens and Quality of Life Measures. In New York, NY: Springer New York; 2010. p. 4355-6. Available from: https://doi.org/10.1007/978-0-387-78665-0 6946

3. Chooi YC, Ding C, Magkos F. The epidemiology of obesity. Metabolism [Internet]. 2019;92:6-10. Available from: https:// linkinghub.elsevier.com/retrieve/pii/S002604951830194X

4. Cheng J, Gao J, Shuai X, Wang G, Tao K. The comprehensive summary of surgical versus non-surgical treatment for obesity: a systematic review and meta-analysis of randomized controlled trials. Oncotarget [Internet]. 2016;7(26). Available from: http://www.oncotarget.com/fulltext/9581

5. Angrisani L, Santonicola A, lovino P, Vitiello A, Higa K, Himpens J, et al. IFSO Worldwide Survey 2016: Primary, Endoluminal, and Revisional Procedures. Obes Surg [Internet]. 2018;28(12):3783-94. Available from: http://link.springer. com/10.1007/s11695-018-3450-2

6. Hess DS, Hess DW. Biliopancreatic Diversion with a Duodenal Switch. Obes Surg [Internet]. 1998;8(3):267-82. Available from: http://link.springer.com/10.1381/096089298765554476

7. Favretti F, Cadiere GB, Segato G, Busetto L, Loffredo A, Vertruyen M, et al. Bariatric Analysis and Reporting Outcome System (BAROS) Applied to Laparoscopic Gastric Banding Patients. Obes Surg [Internet]. 1998;8(5):500-4. Available from: http://link.springer.com/10.1381/096089298765554052

8. Driscoll S, Gregory DM, Fardy JM, Twells LK. Long-term health-related quality of life in bariatric surgery patients: A systematic review and meta-analysis. Obesity [Internet]. 2016;24(1):60-70. Available from: http://doi.wiley.com/10.1002/oby.21322

9. Rausa E, Kelly ME, Galfrascoli E, Aiolfi A, Cavalcoli F, Turati L, et al. Quality of Life and Gastrointestinal Symptoms Following Laparoscopic Roux-en-Y Gastric Bypass and Laparoscopic Sleeve Gastrectomy: a Systematic Review. Obes Surg [Internet]. 2019;29(4):1397-402. Available from: http://link.springer.com/10.1007/s11695-019-03737-3

10. Janik MR, Stanowski E, Paśnik K. Present status of bariatric surgery in Poland. Videosurgery Other Miniinvasive Tech [Internet]. 2016;1:22-5. Available from: http://www.termedia.pl/doi/10.5114/wiitm.2016.58742

11. Ware JE, Sherbourne CD. The MOS 36-Item Short-Form Health Survey (SF-36). Med Care [Internet]. 1992;30(6):473-83. Available from: https://insights.ovid.com/crossref?an=00005650-199206000-00002

12. Lins L, Carvalho FM. SF-36 total score as a single measure of health-related quality of life: Scoping review. SAGE Open Med [Internet]. 2016;4:205031211667172. Available from: http://journals.sagepub.com/doi/10.1177/2050312116671725

13. Oria HE, Moorehead MK. Bariatric Analysis and Reporting Outcome System (BAROS). Obes Surg [Internet]. 1998;8(5):48799. Available from: $\underline{h t t p: / / l i n k . s p r i n g e r . c o m / 10.1381 / 096089298765554043 ~}$

14. Oria HE, Moorehead MK. Updated Bariatric Analysis and Reporting Outcome System (BAROS). Surg Obes Relat Dis [Internet]. 2009;5(1):60-6. Available from: https://linkinghub.elsevier.com/retrieve/pii/S1550728908007739

15. Moorehead MK, Ardelt-Gattinger E, Lechner H, Oria HE. The Validation of the Moorehead-Ardelt Quality of Life Questionnairell.ObesSurg [Internet].2003;13(5):684-92. Available from: http://link.springer.com/10.1381/096089203322509237

16. Kolotkin RL, Crosby RD. Psychometric evaluation of the impact of weight on quality of life-lite questionnaire (IWQOL-Lite) in a community sample. Qual Life Res [Internet]. 2002;11(2):157-71. Available from: https://doi. org/10.1023/A:1015081805439

17. Ware JE, Kosinski M, Dewey JE, Gandek B. How to score and interpret single-item health status measures: a manual for users of the SF-8 health survey. Lincoln, RI Qual Inc. 2001;15(10):5.

18. Eypasch E, Williams JI, Wood-Dauphinee S, Ure BM, Schmulling C, Neugebauer E, et al. Gastrointestinal Quality of Life Index: Development, validation and application of a new instrument. Br J Surg [Internet]. 1995;82(2):216-22. Available from: http://doi.wiley.com/10.1002/bjs.1800820229

19. Figura A, Rose M, Ordemann J, Klapp BF, Ahnis A. Improvement in self-reported eating-related psychopathology and physical health-related quality of life after laparoscopic sleeve gastrectomy: A pre-post analysis and comparison with conservatively treated patients with obesity. Eat Behav [Internet]. 2017;24:17-25. Available from: https://linkinghub. elsevier.com/retrieve/pii/S147101531630143X

20. Kirkil C, Aygen E, Korkmaz MF, Bozan MB. Quality of life after laparoscopic sleeve gastrectomy using BAROSsystem. ABCD Arq Bras Cir Dig (São Paulo) [Internet]. 2018;31(3). Available from: http://www.scielo.br/scielo.php?script=sci arttex$\underline{\mathrm{t} \& \mathrm{pid}=S 0102-67202018000300302 \& \operatorname{lng}=e n \& \mathrm{t} \operatorname{lng}=e n}$

21. Akan S, Uruc F, Aydin MT, Verit A. The effect of sleeve gastrectomy technique on women's sexual function: A prospective study. Rev Int Andrología [Internet]. 2018;16(4):167-73. Available from: https://linkinghub.elsevier.com/retrieve/pii/ $\underline{\text { S1698031X18300207 }}$

22. Charalampakis V, Seretis C, Daskalakis M, Fokoloros C, Karim A, Melissas J. The effect of laparoscopic sleeve gastrectomy on quality of life: A prospective cohort study with 5-years follow-up. Surg Obes Relat Dis [Internet]. 2018;14(11):1652-8. Available from: https://linkinghub.elsevier.com/retrieve/pii/S1550728918303411 
23. Fezzi M, Kolotkin RL, Nedelcu M, Jaussent A, Schaub R, Chauvet MA, et al. Improvement in Quality of Life After Laparoscopic Sleeve Gastrectomy. Obes Surg [Internet]. 2011;21(8):1161-7. Available from: http://link.springer.com/10.1007/ s11695-011-0361-x

24. Gallart-Aragón T, Fernández-Lao C, Galiano-Castillo N, Cantarero-Villanueva I, Lozano-Lozano M, Arroyo-Morales M. Improvements in Health-Related Quality of Life and Pain: A Cohort Study in Obese Patients After Laparoscopic Sleeve Gastrectomy. J Laparoendosc Adv Surg Tech [Internet]. 2018;28(1):53-7. Available from: http://www.liebertpub.com/ doi/10.1089/lap.2017.0415

25. Porta A, Aiolfi A, Musolino C, Antonini I, Zappa MA. Prospective Comparison and Quality of Life for Single-Incision and Conventional Laparoscopic Sleeve Gastrectomy in a Series of Morbidly Obese Patients. Obes Surg [Internet]. 2017;27(3):681-7. Available from: http://link.springer.com/10.1007/s11695-016-2338-2

26. Rebibo L, Verhaeghe $P$, Tasseel-Ponche $S$, Cosse C, Maréchal V, Dhahri A, et al. Does sleeve gastrectomy improve the gait parameters of obese patients? Surg Obes Relat Dis [Internet]. 2016;12(8):1474-81. Available from: https://linkinghub. elsevier.com/retrieve/pii/S1550728916300016

27. D'Hondt M, Vanneste S, Pottel H, Devriendt D, Van Rooy F, Vansteenkiste F. Laparoscopic sleeve gastrectomy as a single-stage procedure for the treatment of morbid obesity and the resulting quality of life, resolution of comorbidities, food tolerance, and 6-year weight loss. Surg Endosc [Internet]. 2011;25(8):2498-504. Available from: http://link.springer.com/10.1007/s00464-011-1572-x

28. Flølo TN, Andersen JR, Kolotkin RL, Aasprang A, Natvig GK, Hufthammer KO, et al. Five-Year Outcomes After Vertical Sleeve Gastrectomy for Severe Obesity: A Prospective Cohort Study. Obes Surg [Internet]. 2017;27(8):1944-51. Available from: http://link.springer.com/10.1007/s11695-017-2605-x

29. Hosseini SV, Al Hurry AMA, Khazraei H, Hadavi H. The Effect of Laparoscopic Sleeve Gastrectomy on Patients' Quality of Life in Shiraz. J Minim Invasive Surg Sci [Internet]. 2018;7(1). Available from: http://minsurgery.com/en/articles/67611.html

30. Bobowicz M, Lehmann A, Orlowski M, Lech P, Michalik M. Preliminary Outcomes 1 Year after Laparoscopic Sleeve Gastrectomy Based on Bariatric Analysis and Reporting Outcome System (BAROS). Obes Surg [Internet]. 2011;21(12):18438. Available from: http://link.springer.com/10.1007/s11695-011-0403-4

31. Sofianos C, Sofianos C. Outcomes of laparoscopic sleeve gastrectomy at a bariatric unit in South Africa. Ann Med Surg [Internet]. 2016;12:37-42. Available from: https://linkinghub.elsevier.com/retrieve/pii/S2049080116301510

32. Hachem A, Brennan L. Quality of Life Outcomes of Bariatric Surgery: A Systematic Review. Obes Surg [Internet]. 2016;26(2):395-409. Available from: http://link.springer.com/10.1007/s11695-015-1940-z

33. Pineda E, Sanchez-Romero LM, Brown M, Jaccard A, Jewell J, Galea G, et al. Forecasting Future Trends in Obesity across Europe: The Value of Improving Surveillance. Obes Facts [Internet]. 2018;11(5):360-71. Available from: https://www. karger.com/Article/FullText/492115

34. Finkelstein EA, Khavjou OA, Thompson H, Trogdon JG, Pan L, Sherry B, et al. Obesity and Severe Obesity Forecasts Through 2030. Am J Prev Med [Internet]. 2012;42(6):563-70. Available from: https://linkinghub.elsevier.com/retrieve/ pii/S0749379712001468

35. Sjöström L, Lindroos A-K, Peltonen M, Torgerson J, Bouchard C, Carlsson B, et al. Lifestyle, Diabetes, and Cardiovascular Risk Factors 10 Years after Bariatric Surgery. N Engl J Med [Internet]. 2004;351(26):2683-93. Available from: https://doi. org/10.1056/NEJMoa035622

36. Fouse T, Brethauer S. Resolution of Comorbidities and Impact on Longevity Following Bariatric and Metabolic Surgery. Surg Clin North Am [Internet]. 2016;96(4):717-32. Available from: https://linkinghub.elsevier.com/retrieve/pii/ $\underline{\text { S003961091630007X }}$

37. Rebecchi F, Allaix ME, Patti MG, Schlottmann F, Morino M. Gastroesophageal reflux disease and morbid obesity: To sleeve or not to sleeve? World J Gastroenterol [Internet]. 2017;23(13):2269. Available from: http://www.wignet.com/10079327/full/v23/i13/2269.htm

38. Kakoulidis TP, Karringer $\AA$, Gloaguen T, Arvidsson D. Initial results with sleeve gastrectomy for patients with class I obesity (BMI 30-35 kg/m2). Surg Obes Relat Dis [Internet]. 2009;5(4):425-8. Available from: https://linkinghub.elsevier.com/ retrieve/pii/S1550728908007375

39. Keren D, Matter I, Rainis T. Sleeve Gastrectomy in Different Age Groups: a Comparative Study of 5-Year Outcomes. Obes Surg [Internet]. 2016;26(2):289-95. Available from: http://link.springer.com/10.1007/s11695-015-1735-2

40. Lainas P, Dammaro C, Gaillard M, Donatelli G, Tranchart H, Dagher I. Safety and short-term outcomes of laparoscopic sleeve gastrectomy for patients over 65 years old with severe obesity. Surg Obes Relat Dis [Internet]. 2018;14(7):952-9. Available from: https://linkinghub.elsevier.com/retrieve/pii/S1550728918301229

41. Boza C, Viscido G, Salinas J, Crovari F, Funke R, Perez G. Laparoscopic sleeve gastrectomy in obese adolescents: results in 51 patients. Surg Obes Relat Dis [Internet]. 2012;8(2):133-7. Available from: https://linkinghub.elsevier.com/retrieve/ pii/S155072891200010X

42. Lauti M, Kularatna M, Pillai A, Hill AG, MacCormick AD. A Randomised Trial of Text Message Support for Reducing Weight Regain Following Sleeve Gastrectomy. Obes Surg [Internet]. 2018;28(8):2178-86. Available from: http://link.springer. $\mathrm{com} / 10.1007 / \mathrm{s} 11695-018-3176-1$ 